\title{
REVIEW OF THE RESEARCH IN CROP WATER REQUIREMENT AND ITS USE IN THE REPUBLIC OF MACEDONIA
}

\author{
Ordan Chukaliev \\ Faculty of Agricultural Sciences and Food, Ss. Cyril and Methodius University, \\ Skopje, Republic of Macedonia \\ e-mail: cukaliev@gmail.com
}

\begin{abstract}
The paper presents a review of the research activities dealing with evapotranspiration (ET), crop water requirement (CWR) and the use of these parameters in other research, particularly in climate change. The first part discusses the development of these research methodologies globally. Later the achievements of the national research are discussed. Macedonia did not developed capacities for measuring of the ET and the crop water requirement. There is only one practice which is followed - field experiments for the assessment of the water balance with bucket approach. The estimation of evapotranspiration is based mainly on the Penman - Monteith FAO 56 procedure. Due to the lack of input data the less data intensive Thornthwhaite methodology is applied. In the country the ET and the crop water requirement are used in irrigation projects, in research activities and in the assessment of the effects of water limitation on crop yield, particularly in climate change. Recently some activities dealing with the use of crop biophysical models WOFOST and CropSyst are taken.
\end{abstract}

Key word: evapotranspiration, crop water requirement, climate change, research, Republic of Macedonia

\section{INTRODUCTION}

The climate determines agricultural productivity. The agricultural production is inextricably linked to climate that makes agriculture the most sensitive economic sector to climate and weather variations, and consequently to climate change.

The temperature drives the crop growth. The global warming in the last century was almost $1^{\circ} \mathrm{C}$, and the first decade of the $21^{\text {st }}$ century was the warmest recorded in history. The global warming is evident. One of the factors that elevates global temperature is the increase of the atmospheric $\mathrm{CO}_{2}$ concentration. The atmospheric $\mathrm{CO}_{2}$ concentration rose from pre-industrial $280 \mathrm{ppm}$ to $402.6 \mathrm{ppm}$ in January 2016 (reported as global average by Earth System Research Laboratory of the National Oceanic and Atmospheric Administration - NOAA). In the last year the increase of the $\mathrm{CO}_{2}$ concentration was for $3 \mathrm{ppm}$, and it is expected that the rise of the global temperature will continue. However, the global warming will affect the precipitation as well. The changes in precipitation are observed and rainfall has increased in the mild latitudes of the North hemisphere. Most of the scenarios for the Republic of Macedonia show a decrease of the annual rainfall. According to the A1B scenario of the Geophysical Fluid Dynamics Laboratory Climate Model 2.1 (US) the slight decrease of the rainfall is expected in the period 2010-2020. After that a period with more significant drop of the rainfall is expected (Sutton et al. [1]).

The changing climate influences the crop and livestock production. Nevertheless, the effects of these biophysical changes and particularly the human response to these changes are very complex and uncertain. Besides the increased temperature, the elevated $\mathrm{CO}_{2}$, fertilization effect promotes the crop growth. But it is important to take Liebig's law of the minimum into consideration to understand the effect of the global changes. These changes should be analyzed from the point of the most lim- 
iting factor in the production and in Macedonia this is the water limitation. The yield in most of the agricultural areas in the country is limited by water. Due to this limitation about $1 / 4$ of the cultivated land is equipped for irrigation. Unfortunately the irrigated area dropped from more than 80 thousand hectares in the 1980s to about 30 thousands ha nowadays. The climate change will also cause more frequent appearance of extreme events as drought, floods, heat waves, etc. It is expected that these extreme events, in combination with present water limitation, will further increase the negative effects on the agricultural productivity in the country.

Due to this the researchers in the country focus their attention to the effect of water limitation on the crop yield in present and future climatic conditions. This paper aims to present the current research efforts in Macedonia to address the ET, crop water requirement and crop yields in present and future climatic conditions.

\section{Reference evapotranspiration and crop water requirement}

Basically crop water requirement is ET adjusted for crop species and growth stages. Various methods for estimation of evapotranspiration are in use. Direct measurement is considered as one of the best practices, particularly the use of weighted lysimeters (Mustonen and McGuinness [2], Hargreave [3]; Pruitt and Lourence [4], Howell et al. [5]; Liu et al. [6]; López-Urrea et al. [7]; Toyin et al. [8]). The weighted lysimeters are in use for a long period of time and still considered to be the most accurate way to estimate crop water use and develop crop specific coefficients. Therefore they are regarded as a standard for determination of the ET. The weighted lysimeters measure the changes in mass of a soil container planted with investigated crop and these changes are representing water used in a certain period. Even though the weighted lysimeters are in use since the late 1930s, they are still used for testing, and comparing of the results from the new practices as Bowen ratio, Eddy covariance, remote sensing, etc. (Dugas et al. [9]; Barr et al. [10]; Wolf et al. [11]; Gebler et al. [12]; Reginato et al. [13]; Chávez et al. [14]; Cruz-Blanco et al. [15]). Even more, the lysimeters are used for development of new empirical methods for estimation of ET and calibration of the empirical and biophysical models for estimating of the ET (Abtew and Obeysekera et al. [16]; Kashyap and Panda et al. [17]; Marsal et al. [18]; Reddy [19]). Finally lysimeters are used for operational irrigation scheduling.

The various authors were developing empirical methods for estimation of ET (Thornthwaite [20]; Penman [21]; Blaney et al. [22]; Blaney and Criddle [23]; Harbeck [24]; Priestley and Taylor [25]; Hargreaves [26]; Hargreaves and Samani [27], etc.). The existing methods for the estimation of potential ET are based on high correlation of ET with some measurable parameters as temperature (Thornthwaite [20]; Blaney and Criddle [22]; Hargreaves [26]; Hargreaves and Samani [27]), radiation (Priestley and Taylor [25]; Jensen and Haise [28]), mass-transfer (Harbeck [24]) or combination of some of these parameters (Penman [21]).

Table 1. The methods for estimation of the ET and measurable parameter correlated with ET

\begin{tabular}{lcc}
\hline \multirow{2}{*}{ Method for estimation of ET } & \multicolumn{2}{c}{ Method based on correlation with } \\
\cline { 2 - 3 } & temperature & radiation \\
\hline Penman-Monteith & $\mathrm{x}$ & $\mathrm{x}$ \\
Hargreaves/Hargreaves Samani & $\mathrm{x}$ & \\
Thornthwaite Method & $\mathrm{x}$ & \\
Blaney-Criddle Method & $\mathrm{x}$ & $\mathrm{x}$ \\
Priestley-Taylor & $\mathrm{x}$ & $\mathrm{x}$ \\
Makkink Method & & $\mathrm{x}$ \\
Turc Method & & $\mathrm{x}$ \\
Jensen and Heise & & \\
\hline
\end{tabular}

The Penman method modified by Monteith [29] became a standard for estimating of reference evapotranspiration (ETo) particularly due to the work of Doorenbos and Pruitt [30] when they pro- posed the Penman-Monteith procedure as one of the 4 standard methods for estimation of reference evapotranspiration (defined as ET rate from a reference surface, not short of water). The reference sur- 
face is a hypothetical grass reference crop with specific characteristics. The reference evapotranspiration is considered as a climatic parameter and can be computed from weather data, and only weather data can affect it. Moreover, the FAO consultation process resulted in a proposal for revision of the methodology proposed by Doorenbos and Pruitt [30] which led to the publication of the FAO Irrigation and drainage paper 56 entitled "Crop Evapotranspiration - Guidelines for computing crop water requirements" (Allen et al. [31]). With these guidelines a hypothetical reference crop was defined with assumed crop height of $0.12 \mathrm{~m}$, a fixed surface resistance of $70 \mathrm{~s} \mathrm{~m}^{-1}$ and an albedo of 0.23 . The FAO Penman-Monteith method is selected as a reference method by which the ET of this reference surface (ETo) can be unambiguously determined, and as a method which provides consistent ETo values in all regions and climates. Moreover, the American Society of Civil Engineers (ASCE) conducted extensive consultations on standardization of the procedures for ET estimates. As a result of this process Walter et al. [32] recommended two reference crops (short similar to grass and high similar to alfalfa) and ASCE Penman-Monteith (ASCE-PM) equation with some simplifications as a standard method. Later an extensive comparison of the number of methods for estimation of the ETo was conducted by Itenfisu et al. [33]. The researchers used hourly and daily weather data from 49 geographically diverse sites in the United States. Calculations were performed for both grass and alfalfa reference crops in a consistent manner, using weather data that passed integrity and quality assessment checks. Comparisons were made between ETo computed by various methods and the ASCEPM equation for a daily calculation time step. Results showed that the ASCE standardized equation agreed best with the full form of ASCE-PM and provided a basis for an objective assessment of the relative performance of reference ET equations in a variety of climates and supported adoption of a standardized equation.

\section{From reference evapotranspiration to crop water requirement}

The reference evapotranspiration is exclusively a climatic parameter and should be converted into the crop evapotranspiration (ETcrop). The FAO 24 methodology (Doorenbos and Pruitt [30]) recommended the use of the growth stage specific crop coefficient $(\mathrm{kc})$ to relate ETo to ETcrop in order to account for the effect of the crop characteristics on crop water requirements. Besides climate and climate induced variations of the reference evapotranspiration, the ETcrop is affected by numerous factors that further influence crop water requirement, such as: crop phenology, cultural practices, irrigation method, soil water availability, etc. Therefore the FAO organized an expert consultation that was held in May 1990 in Rome and established a working group for revision of the FAO 24 methodology. This working group revised the methodology (Allen et al. [34]; Allen et al. [31]). This revision included modified procedures for estimating crop coefficients $(\mathrm{kc})$. The single and dual crop coefficients were introduced for estimation of crop water requirement in standard condition. Moreover, the detailed procedures were provided for non-standard condition through adjusting of the crop coefficient. This procedure became a standard for estimation of the ET and crop water requirement for irrigation projects and many others applications. The work on calibration of the FAO 56 and growth stage specific crop coefficients for various crop in different climatic conditions is still ongoing in many environments (Yang et al. [35]; Tian et al. [36]; Aamlid et al. [37]; Muniandy et al. [38]; Campos et al. [39]; Paparrizos et al. [40]).

\section{RESEARCH IN EVAPOTRANSPIRATION AND CROP WATER REQUIREMENT IN THE REPUBLIC OF MACEDONIA}

\section{Determination of the evapotranspiration and crop water requirement}

The measurement of the ET and crop water use in Macedonia is still far away from modern scientific achievements. Unfortunately in the Republic of Macedonia there are not any weighted lysimeters installed. Also there is not any other lysimetric type used in practice. The cost of installation of the weighted lysimeter field is overcoming the capacities in the country. Unfortunately, after the transition period it was quite difficult for the scientific community to keep pace with modern technologies used for determination of ET such as remote sensing, Bowen ratio, Eddy covariance, etc. Nevertheless, the Macedonian researchers are doing their best to determine ET and get information on crop water requirement of various crops in the country. The first paper on measurement of ET and crop water requirements was published by Kosevski [41]. This paper introduced the experimental determination of the ETcrop using the soil water budget practice, particularly using the bucket approach (assuming that there is not flux of water from and into the root zone). This practice still re- 
mains as a standard method to determine ET in the country. The paper presented data on crop water requirement of maize planted in two regions (Skopsko Pole and Polog). Further this practice was used by Iljovski [42] when he determined crop water requirement and water use of hop in various regimes of water supply in Pelagonia. Furthermore Iljovski et al. [43] presented the effect of irrigation technique on crop water use. Iljovski and Chukaliev [44] presented crop water requirement for sunflower cultivated as second crop using the same experimental method for determination of the ET, crop water requirement and irrigation water requirement. The similar research was carried out by Chukaliev and Iljovski [45] that presented results on crop water use of maize cultivated as second crop. Iljovski et al. [46] conducted research on the determination of the crop water use for sugar beet cultivated as second crop, using same methods. Furthermore Chukaliev and Iljovski [47] published a work on a three-year experiment for determination of water consumption of sugar beet irrigated by micro-sprinkler irrigation, sprinkler irrigation and furrow irrigation. Their results demonstrated that similar ET could result in different yields if water was applied with different irrigation techniques. Therefore the micro-sprinkler irrigation that increased air humidity alongside of soil moisture, achieved higher yield even though the ET was similar to sprinkler irrigation one. The authors concluded that if water was applied in small portions several times per day, the water use efficiency of the sugar beet could be increased. Based on previous work, Iljovski and Chukaliev [48] presented initial results on crop water requirement and water use of sugar beet by applying different irrigation techniques (pulse irrigation, sprinkler and furrow, compared with non-irrigated treatment). Later, Chukaliev [49] presented final results on the crop water requirement, water use and water use efficiency of sugar beet planted in Skopsko Pole with particular emphasis on pulse irrigation (application of fine drops of water in very small portions several times per day). This work proved that even though ET was determined by meteorological conditions, irrigation could change some of these parameters within the crop canopy (decrease of temperature, increase of air humidity) and reduce crop water requirement. The pulse irrigation resulted in higher yield and sugar content with smaller/similar use of water as sprinkler and furrow irrigation. Iljovski and Chukaliev [50] conducted research on the crop water requirement for the young apple orchard and reported much lower crop water requirement than in full developed orchards. Iljovski et al. [51] conducted research on comparison of crop water use with application of furrow and drip irrigation and confirmed that tomato crop under drip irrigation used water more efficiently in comparison with furrow irrigation. Furthermore, Iljovski and Chukaliev [52] presented results on crop water use for tomato crop irrigated by drip irrigation, by combination of micro-sprinkler and drip irrigation and by furrow irrigation. The tomato irrigated by drip irrigation used just two thirds of the water used in furrow irrigation and achieved 30\% higher yield. The sporadic intervention with micro-sprinklers did not increase the yield, but had an effect on earlier maturity. The very similar concept for the determination of the crop water use was used in the research of Iljovski and Chukaliev [53]. They presented results for ET and crop water use for alfalfa irrigated by pulse irrigation and by sprinkler irrigation and concluded that pulse irrigation used less water (by almost 30\%) and achieved higher yield (by around 20\%). Moreover, the similar type of experiment was conducted in the research on the effects of water conservation on crop water use. Iljovski et al. [54] presented results that different types of soil mulch (polyethylene and straw) affected crop water use. The highest water use was observed in not mulched treatment, while the lowest in the treatment with polyethylene mulch. The authors reported that in the case of polyethylene mulch higher root density was recorded in the top soil layers that resulted in over extraction of water from these layers while straw mulch resulted in higher water consumption from deeper soil layers. The mulching conserved water in the soil and resulted in lower crop water use. Chukaliev and Iljovski [55] published their new results on comparative research of water use of tomato crop using drip and furrow irrigation. Once again they recorded higher water use efficiency of tomato when drip irrigation was used.

Later Jankulovski et al. [56] presented results from the field experiments they carried out for determination of ET under different irrigation regimes. Their research was particularly oriented to water use efficiency. The highest water use efficiency was determined when irrigation water was applied at depletion level of $50 \%$ of total available water (TAW) of $66 \mathrm{l} / \mathrm{kg}$. Similar result of $68 \mathrm{l} / \mathrm{kg}$ was achieved when irrigation water was applied according to the soil water balance as recommended by Iljovski [57], Cukaliev [58], Cukaliev and Iljovski [59] and Chukaliev and Iljovski [60]. Other treatments used the water less efficiently. Jankulovski [61] presented additional results of the effect of irrigation regime and amount of fertilizers on sugar beet yield. The highest yield was achieved when water was applied at $50 \%$ of TAW followed by irrigation according to 
the water balance with yield lower by $7 \%$. Also they proved that the increase in the quantity of fertilizers in these treatments resulted in higher yield and increased water use efficiency.

Tanasković V. [62] continued the practice to use field experiments for determination of ET by application of the water balance method. Unlike previous authors his experiments were based on the use of drip irrigation resulting in substantially improved control of applied water. Moreover, he applied same amount of water for each treatment based on daily ET. The author used different frequency of irrigation/fertigation (every 2 days, every 4 days and every 6 days). The comparison of the achieved results was done with treatment irrigated every 4 days, but fertilizers were applied in granular form and incorporated into the soil. All fertigation treatments compared with classical fertilization practice achieved higher yield. Also treatments of the applying water and fertilizers every 2 and 4 days achieved significantly higher yield compared with 6 days frequency of fertigation. The yields in fertigation treatments were very high, about 120 $150 \mathrm{t} / \mathrm{ha}$. The same water amount (same ET) yielded in different productivity of the tomato crop, just due to the frequency of application of water which should be considered as one of the factors that affected crop water requirement and water use efficiency. Later, work of Tanaskovik V et al. [63] and [64] presented additional explanation of the findings of Tanasković V. [62].

Chukaliev O et al. [65] presented results on nitrogen use efficiency under different irrigation regimes and found that irrigation regime affected the nitrogen uptake by the tomato crop. They used $\mathrm{N}^{15}$ labelled nitrogen fertilizer and provided data that increased water use efficiency reflected on increased nitrogen use efficiency. The work of Jankulovski et al. [61], Tanasković [62], Tanasković et al. [63] and [64] and Chukaliev et al. [65], provided valuable data for future work on calibration of ET based on fertilization level and fertilizers and water use efficiency.

Tanasković [66] presented results on use of soil water balance for determination of evapotranspiration on pepper crop. The basis for irrigation scheduling was the daily evapotranspiration calculated by the FAO 56 procedure. He used 3 drip fertigation treatments (every 2 days, every 4 days and irrigation based on tensiometric measurement of soil water potential). The comparison was done with furrow irrigated pepper crop. The crop evapotranspiration in his research was about $490 \mathrm{~mm}$ when using drip irrigation scheduled according to daily evapotranspiration, $510 \mathrm{~mm}$ when using tensiometers and $590 \mathrm{~mm}$ when using furrow irriga- tion. The highest yield was recorded in 2 days fertigation scheduling of about $71 \mathrm{t} / \mathrm{ha}$ that was significantly higher than in both treatments using higher amount of water (scheduling by tensiometers and furrow irrigation).

Next several papers published by Tanasković et al. [67], [68], [69] and [70] and Chukaliev et al. [71] contributed to the work of Tanasković [62] and [66] and presented a valuable source of data for calibration and validation of crop models, but did not bring any new research on the use of evapotranspiration and crop water requirement.

Probably the research of Tanasković [66] was the last attempt for direct determination of the crop water use because in the last period of time there was almost no financing of the national research. This type of research activities is quite obsolete and it is very difficult to get international grants that will support projects based on this methodology. It is even harder to get financial support for constructing weighted lysimeters or equipment for more advanced measurement of evapotranspiration and crop water requirement. Building of lysimeters is very costly. Even when they are constructed, researchers interested in this issue can not provide sustainability of the lysimetric fields, particularly owing to the lack of national financing of the research activities. The problems are accelerated due to the fact that during the privatization the experimental fields of the scientific institutions became private entities, and got more interested in commercial production than in non-commercial use of their land in research purposes. Therefore researchers in the country are moving their interest to other fields, even though it is essential to have data on measured evapotranspiration and crop water requirement, particularly related to the changing climate. Although in the country there is a lack of recent experimental data on calibrating and validating models and other advanced research techniques, we can say that lately there has not been any research conducted in this issue as well.

\section{Estimation of evapotranspiration and crop water requirement}

The estimation of evapotranspiration was mainly used in the design purposes, and most of designers used the consumptive use equation developed by Blaney and Criddle [23]. This topic was not attractive for research during that period, and designers were using the coefficients derived from other countries. The research on the estimation of evapotranspiration and crop water requirement started in the early 1960s, when Petrovski [72] pub- 
lished his paper on water regime in Skopsko Pole. Later the use of estimation of the evapotranspiration and crop water requirement gradually improved. Cosevski and Popov [73] and Iljovski et al. [74] were trying to derive some calibration and to correlate temperature with water use, but these attempts were limited to one location. The first paper on the use of temperature correlated with crop water use was published by Iljovski [57]. He established correlation coefficients between crop water requirement and temperature for hop based on the extensive field experiments. Later, the same author (Iljovski [75]) presented the needs of estimating crop water requirement with methods that were calibrated for a given condition, particularly in designing larger scale accumulation for irrigation. The first attempt to develop model of the crop water requirement based on reduced input was done by Chukaliev [58]. He developed empirical model for balancing the soil water content based on daily values of the temperature and precipitation and applied it for simulation of irrigation of grain maize. Chukaliev and Iljovski [59] implemented similar model for simulating the crop water requirement for apricot grown in the area of the irrigation system Lisiche in Veles municipality in order to predict number of irrigations and application rate. Due to unavailability of meteorological data in the country, the authors used a reduced input dataset with just few parameters (temperature, rainfall and soil water properties). The authors recommended the use of such model for irrigation scheduling when only temperature and precipitation data are available. Chukaliev and Iljovski [60] used the same model as in their previous work on apricot for tomato crop and reported that models with reduced input of meteorological data can be used for irrigation scheduling if carefully calibrated with measured data on crop water requirement from experimental fields.

This early work did not take into consideration the various developed practices for estimation of the evapotranspiration. While the FAO 24 methodology was widely used in the world, the research in Macedonia was not able to keep pace with this processes mainly due to lack of measured data on wind and solar radiation. The other disadvantage was that this research was very site specific (conducted for one meteorological station and for crops that were in experimental fields and where data for calibration was available). One of the first attempts to estimate evapotranspiration and water requirement on the larger scale (country level) was conducted by Iljovski and Chukaliev [77]. Unfortunately this work was using aggregated data on evapotranspiration and rainfall on the country scale and can be used therefore only as orientation, because it did not provide proper spatial analysis of these important parameters. The more complex work on estimation of evapotranspiration all over the country was conducted by Filipovski et al. [78]. In this work the authors presented data for evapotranspiration and water availability for all main meteorological stations in the country. The method of choice was Thornthwaite [20] due to reduced data availability, but also this method is good for description of the climatic water balance for climatological work. Moreover, this work was conducted for determination of soil-climate-vegetation zones and therefore did not intend to be the source of data for crop water requirement for use in an irrigation project.

The first attempt to use the FAO 24 methodology and Penman-Monteith equation was made by Iljovski and Chukaliev [79]. Next year the same authors (Iljovski and Chukaliev [80]) presented the paper where they discussed methods for estimation of evapotranspiration and crop water requirement. They compared the methods for estimation of the evapotranspiration and recommend the FAO 24 Penman-Monteith procedure for use in the irrigation projects. This happened very late, in the same year when Allen et al. [31] proposed revision of the FAO24 procedures for estimation of evapotranspiration, and new procedures published in the FAO 56 guidelines for estimation of the evapotranspiration (Allen et al. [34]) were already appreciated. The late adoption of FAO 24 procedures was due to crisis in Former Yugoslavia and the long transition period after the independence of the Republic of Macedonia. In that period the access to new scientific literature was almost impossible and the financing of the research required for calibration of the crop specific coefficient was not available. In addition, the use of the procedures which are intensive in requirement of various meteorological data (as Penman-Monteith procedure is) was limited to the monthly step for several main meteorological stations where all required data was monitored. Unfortunately, the problem of transparency of meteorological data remains major problem in development of more advanced research in crop water requirement particularly in the use of PenmanMonteith procedures and in application of the crop empirical and biophysical models.

Furthermore Chukaliev et al. [81] presented research in the effects of evapotranspiration and water deficit on the yield of winter wheat planted in Pelagonia area. The agricultural production in the country is water limited, so authors tried to determine the yield reduction as a result of water limitation. They considered the winter wheat grown in Pelagonia region as usually non-irrigated crop, therefore very prone to reduced yield as a result of water limitation. 

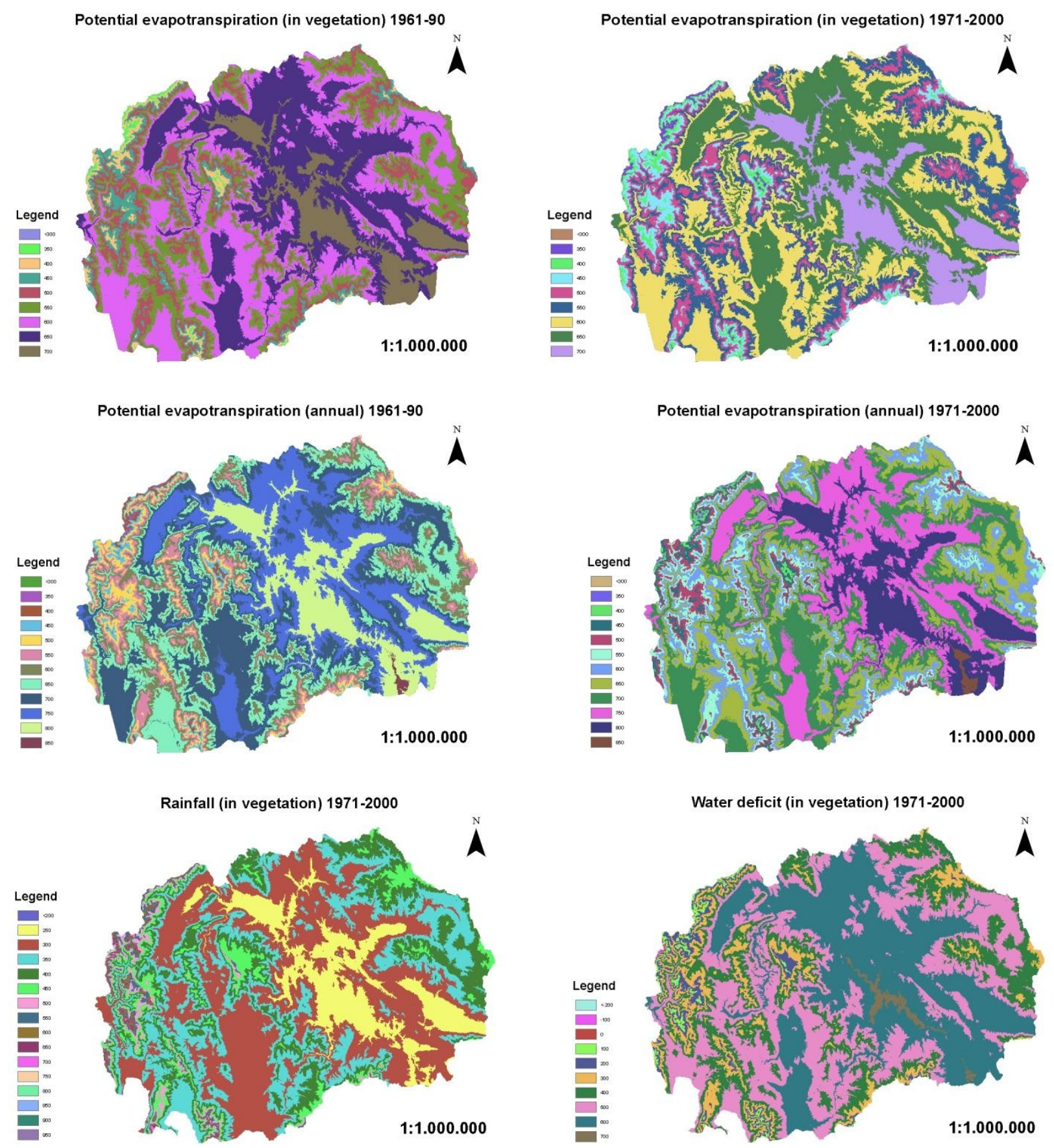

Figure 1. Potential evaporation (annual and for growing season) in period 1961-1990 and 1971-2000, rainfall and water deficit in the growing season for period 1971-2000 (Chukaliev [87])

The methodology applied was FAO Crop yield response to water deficit (Doorenbos and Kassam [82]), known as FAO Irrigation and Drainage Paper No. 33 or FAO 33. The 5-year period was analyzed and authors reported water deficiency of $19 \%$ in average that resulted in yield decrease by $28 \%$, that was unexpected result and pointed to appearance of water deficit in the very sensitive stage for water deficit. This was the first paper published on the use of this methodology, almost 20 years after it was introduced. Nevertheless, this methodology would be of great use in the future research conducted on effects of climate change on crop yield in the country. This methodology was long lasting and its update was presented in Steduto et al. [83].

Ančev et al. [84] presented their work on effect of the drought on the crop yield. They presented potential and real evapotranspiration calculated by Thornthwaite [20] methodology for several agricultural regions in the country and determined the 
climatic water balance. The climatic water balance for all regions was negative; water deficit is therefore an important factor that limits crop yield in the country. Ančev et al. [85] provided extensive summary on the effect of drought on agricultural production and on the environment. They provided data for potential evapotranspiration for the period 1951-1990. Moreover, the paper compared the yield of the agricultural crops in years with different drought intensity and provided beneficial results for further elaboration of the crop yield response to water deficit.

Iljovski et al. [86] presented their research in the importance of accurate determination of irrigation water requirement in preparation of the Water Master Plan of the country. They presented their results on the use of Penman-Monteith FAO56 procedure and estimated that amount of water for irrigation of the potential 390000 ha was about 2 billion $\mathrm{m}^{3}$.

More complex work on estimating evapotranspiration was done by Chukaliev [87] for preparation of the First National Communication of the Republic of Macedonia to UNFCCC [87]. The maps of the spatial distribution of the evapotranspiration were prepared for the two 30-year periods (1961-1990 and 1971-2000). The maps for both periods were compared and showed an increase of evapotranspiration in major agricultural regions in the country. The method of choice was Thornthwhaite [20], due to the low level of availability of the data required to use the FAO 56 Penman-Monteith procedure. Moreover, the maps of the efficient rainfall and water deficit were produced for the same period. With this work the geospatial distribution of the evapotranspiration in the country was provided for the first time.

Tanasković et al. [88] and [89] gave their contribution to the calibration of the methods for estimation of the evapotranspiration and crop water requirement for pepper crop, providing data for different crop growth stages and different irrigation techniques and irrigation practices.

\section{Research in climate change vulnerability assessment and adaptation measures based on evapotranspiration and crop water requirement}

The first paper on the effect of climate change on agricultural sector was published by Chukaliev et al. [90]. The authors discussed the effect of the increased temperature on evapotranspiration using FAO 56 procedure and provided data for two important agricultural regions (Bitola and Stip) on the average values of the referent evapotranspiration, for the period 1961-1998 and in two climate change cases (increase of temperature for 1 ${ }^{\circ} \mathrm{C}$ and for $2{ }^{\circ} \mathrm{C}$ ). In order to determine the irrigation water requirement they applied different procedures in estimating the efficient rain as recommended in the FAO Irrigation and drainage paper No 25 (Dastane [91]). The simulation was done by using FAO CROPWAT software. In this work authors concluded that using of this procedure for estimating the effect of climate change on irrigation water requirement was very risky because the choice of the method for estimation of the effective rainfall was making much bigger difference than the effect of increased temperature itself.

Later Chukaliev and his team started the work on vulnerability assessment and adaptation measures of the agricultural sector for the purpose of preparation of the First National Communication to the United Nation Framework convention on Climate Change (UNFCCC) (Group of authors, [92]). This work was the first attempt for larger scale addressing of climate change in agricultural sector. The extensive literature review was conducted and team faced with a serious challenge to conduct this research based on very limited data (average monthly temperatures and precipitation for the period 1961-90 for the major meteorological stations in the country). The previous experience with water limitation and the use of drought indices for assessment of drought served as a starting point and the most vulnerable regions were determined as regions with the highest increase of dryness as compared to the reference period. The most vulnerable zone was Povardarie region, especially the area of the conjunction of Crna and Bregalnica River with Vardar River. Very vulnerable zones were: the southeastern part of the country (Strumica), Southern Vardar valley (Gevgelija), Skopje-Kumanovo Valley and Ovche Pole. The most vulnerable crops were determined as the most important crops in the vulnerable regions as follow: vine grape in Povardarie region; tomato in South and South Eastern part of the country; winter wheat in Skopje -Kumanovo and Ovche Pole area; apple in big lakes region, particularly Resen and alfalfa as crop with very high water demand and huge importance in livestock sector in all agricultural regions in the country. Having in mind that even at present the most important limiting factor of crop production is water deficit, the authors applied FAO Crop Yield Response to Water Deficit Approach. The crop evapotranspiration in reference period was used as potential, and crop evapotranspiration in climate change case was used as actual evapotranspiration. The reference period crop yield was used as potential, and the yield with climate 
change was the actual one. This was done for all of the most vulnerable crops and regions using the FAO 56 methodology, but the evapotranspiration calculated by Thornthwhaite [20] was assumed as reference transpiration. The biggest limitation of this approach was that it was not possible to evaluate the effect of the proposed adaptation measures. This was a very rough approach, but due to the limited data availability it was impossible to conduct more precise research in that period.

The same team worked on the vulnerability and adaptation of agricultural sector report for the preparation of the Second national communication to UNFCCC (Group of authors, [87]). Again very limited data set was available, monthly values for temperature and precipitation for two periods 1961-1990 and 1971-2000. The team faced the same problems particularly with the evaluation of the yield response to climate change and the adaptation measures. The insufficient data, made almost impossible the application of some of the existing crop models. There was a substantial improvement in biophysical crop modelling in the period between two national communications and several models were extensively used in climate change studies as WOFOST (Diepen et al. [93]), CropSyst (Stöckle et al. [94]), DSSAT (Jones et al. [95]), STICS (Brisson et al. [96]), etc. Moreover, the problem was that there was no financing of national research that would enable the development of capacities for using biophysical crop models. On the other hand, the research team developed new capacities for using GIS and spatial numerical modelling. So the vulnerability assessment was conducted in GIS, and various thematic maps were developed for drought indices, evapotranspiration (estimated with Thorntwaite method), effective rainfall, climatic water deficit, etc. These maps were developed for the both investigated periods and provided an excellent overview of the vulnerable regions in the country. The most vulnerable region appeared to be the central part of the Vardar River catchment. The effect of the changed climate on the crop yield was again predicted using FAO Crop Yield Response to water deficit as previously explained. In this research there was much better addressing to the climate change with an evaluation of the periods of the years 2025, 2050 and 2100. But there was still a similar weakness as in the previous communication.

For the preparation of the third national communication to UNFCCC (Group of authors [97]) an extensive cooperation with the Joint Research Center of the European Commission from Ispra, Italy, was established. The most advanced methods were used as biophysical model applica- tions - BioMA (BioMA [98]). The BioMA is a modelling platform that combines several models. In the preparation of the third national assessment of vulnerability and adaptation of the agricultural sector two models were used: ClimIndices model for assessment of the vulnerability to climate change and CropSyst model for assessment of the impact of the adaptation measures to climate change. Moreover, the data set used for historical weather, as well as for climate change weather, were sourced from JRC (MARS weather database for historical data and climate change weather data generated with a stochastic weather generator trained over RCM-GCM downscaled simulation from the ENSEMBLES project). The weather data used were grid weather with the grid size $25 \times 25$ $\mathrm{km}$. The report addressed the South Eastern part of the country distributed in 7 grids. This report is the most extensive work on the climate change and its effect on agriculture, and probably the best source of evapotranspiration calculated by means of the biophysical model. A similar approach was used by Mukaetov et al. [99] for assessment of the climate change impact on viticulture in Povardarie region. The adaptation practices tested in this work showed a need for dislocation of the grape on higher elevation and increased crop water requirement.

The use of crop water requirement data for estimation of the economical losses caused by the climate change and of the costs of the adaptation measures in the country was conducted by Callaway [100]. The crop water requirement was determined for the reference case and for climate change case using FAO 56 Penman-Monteith procedure. The damages of the climate change were based on yield reduction. Further, two adaptation options were applied. The first adaptation case was supplemental irrigation (to irrigate rain-fed area with amount of water required to maintain base case yield). The second case was using full irrigation. The research was conducted for the irrigation system of Streževo and the authors used two time frames (years 2050 and 2100). The climate change scenario was developed by Bergant [101] and 3 levels of impact were used (low, medium and high). The researchers found that by 2050 , the climate change damages in the rain-fed part of the region for the most severe climate change scenario roughly equalled the net income in the reference case. For the irrigated part of the agricultural sector in this region, the magnitude of the climate change induced damages reached the level of net income in the reference case by 2100 under the medium climate change scenario - and far surpassed the reference case net income levels under the high climate 
change scenario. The net adaptation benefits were positive in all cases that showed that the economic benefits of these measures would be greater than their costs.

Buzarovska [102] used the same data set as Callaway [100] in her research on the optimization of agricultural production under climate change for Pelagonia Region. Her research aimed to illustrate the variation in crop area in Pelagonia region in 2050 due to the increased irrigation requirements of crops. The allocation of the crop area depended on the net return per unit of crop area. On the other hand, the net return was strongly related to the irrigation water requirements. Both, rain-fed and irrigated crops were expected to have higher water demand driven by the higher temperatures and reduced soil moisture because of the decreased precipitation and runoffs. The author used three climate scenarios for 2050 (low, medium and high impact). The climate change scenarios were subject to comparison with the Base case scenario. The technique of linear optimization was used to identify the best cropping pattern under given constraints. The findings of the study showed that due to climate divergences in 2050, the crop structure differed in various climate scenarios. In general, the more severe climate in 2050 will cause decrease in net returns by $11 \%$ in the most optimistic scenario (2050 Low) and $22 \%$ in the pessimistic scenario (2050 High), if no adaptation measures are applied. The production of the low profitable crops (cereals, industrial and fodder crops) will be reduced to their minimal levels, while the production of high profitable crops such as vegetable, especially green pepper, tobacco and other crops that increase net return per crop area would be intensified.

Even though the following research was conducted on European scale, it is presented here because the national researchers participated in these activities, so we can consider it as a national achievement. The research of the Duvellier et al. [103] analyzed the change of inter-annual variability of agro-climatic indices calculated for the major environmental zones in Europe from a baseline climate in 2000 to a projected climate in 2030. It leveraged on a future daily weather dataset based on 2 contrasting realizations of scenario A1B by global circulation models (GCMs), dynamically downscaled with regional climate models (RCM) that have been bias-corrected. Agro-climatic indices were calculated using the ClimIndices software package. Although more than 100 indices were systematically calculated only 4 were presented (Growing Season Start, Growing Season Length, Last Air Frost Spring and Dry Spell). Both climate projections showed an increase in the growing season length for all zones without any considerable increase in variability. This would be partly caused by an earlier start of the season. The changes in late frost dates were not apparent, warning that although the earlier sowing of crops could be beneficial to have a longer growth cycle, the crops might potentially be exposed more to frost damage. A clear pattern of longer and more variable (from year-toyear) periods of consecutive dry days was determined in the Mediterranean and Pannonian regions

Ceglar et al. [104] used the Bio-physical Model Applications framework (BioMA) to simulate the maize yield response to water availability in current and future climatic conditions. Two different realizations of the A1B scenario from dynamically downscaled global circulation models within the ENSEMBLES project, which capture the most contrasting situations with respect to changes in precipitation and temperature, have been selected for this purpose. The CropSyst crop model was used to simulate the water-limited and potential maize yield, as well as total crop water requirement and total water consumption. The water deficit productivity index was introduced for the purpose of the study, describing the gain in crop yield when water deficit was reduced. The results showed that the maize yield was expected to decrease in Southern Europe as well as in the regions around the Black Sea during the 2030s. The water could become more productive in Central and Western Europe and slightly less productive in the Southern Europe.

Ceglar et al. [105] analyzed the spatial distribution of water demand for irrigation as a prerequisite to devise an appropriate water management strategies, which could stabilize crop production. In order to assess the effect of irrigation on crop yield, the experiment was conducted on grain maize, well-known as a crop sensitive to water deficit and drought. The spatial distribution of water deficit and maize yield deficit across Europe was simulated with the WOFOST model and compared between current and expected climatic conditions in 2030s. In our study, the priority has been given to future projections of the A1B emission scenario given by two contrasting regional climate model runs (in terms of projected air temperature change) within the ENSEMBLES project. The effectiveness of three irrigation strategies was compared, which could potentially be applied to offset the adverse climate change impact on grain maize yield in Europe: full, deficit and supplemental irrigation. The results showed that similar yields could be achieved using deficit irrigation strategy, when compared to full irrigation, thereby saving at least $30 \%$ of irriga- 
tion water in the current and future climate conditions.

This review will end with the last published paper on the use of evapotranspiration and crop water requirement for assessment of the impact of climate change and determination of the best adaptation options. Dimov et al. [106] presented the research in the changes in productivity of the winter wheat and sunflower as a result of changing climate. The biomass yield of the winter wheat without adaptation will decrease by $23 \%$ in 2025 and by $27 \%$ in 2050 . Very similar reduction is expected for grain yield. The grain yield of the sunflower will decrease by $30 \%$ in year 2025 and by $40 \%$ in year 2050 without adaptation. The adaptation strategy for winter wheat composed of later sowing (mid to end of November) and sprinkler irrigation will reduce the impact of climate change. The adaptation strategy of 4 irrigations of sunflower by sprinkler irrigation showed the best effect on the sunflower yield and reduced the negative impact of climate change.

\section{CONCLUSION}

The national capacities for measuring the evapotranspiration and crop water requirement are extremely limited. There are not installed lysimeters. In addition, there is no equipment for use of other advanced technologies for measurement of the evapotranspiration and crop water requirement. For more than 50 years the scientific community in the country has been using the same approach for determination of the ET: the field experiments for determination of the water balance with bucket approach. Even though this is an old-fashioned technology, the extensive research activities were conducted and there were significant data accumulated for use in calibration and validation of more advanced technologies.

The capacities for assessment of the evapotranspiration and crop water requirement using the procedures that are highly appreciated by international scientific community (FAO 56 and ASCEPM) exists, but the national researchers do not have experience with the ASCE-PM procedure and appreciate FAO56 and the use of the FAO CROPWAT software. The problem is that climate data in the country are hardly available and very expensive, so that a limited number of research activities is conducted. Due to the lack of climate and meteorological data a lot of efforts were made to calibrate simple temperature based procedures for estimation of the evapotranspiration and crop water requirement and to recommend these procedures for use in irrigation scheduling.
The crop yield response to deficit water is a well established methodology in the country because there are no capacities to use more complex biophysical models that operate not only with water deficit, but also take into consideration many other parameters affecting crop yield. Even though certain attempts on the use of CropSyst and WOFOST were made in the last several years, a trained researcher can not continue with this activities due to the shortage of data required (meteorological and phenological data are almost not available).

The capacity to assess the vulnerability to climate change is well developed. Unfortunately capacities for modelling the crop response to changing climate and to the adaptation practices need a serious reconsideration. In the last period national scientists gain some experience in using of WOFOST and CropSyst biophysical models, but it is quite difficult to provide sustainable use of these models due to the lack of data required to run these models. The use of the biophysical models should be increased, but also the use of the empirical models should be initiated, and probably these models with lower need for data not available in the country can be a solution for the operational activities. The research should be aimed towards filling of the gaps and using of Earth Observation and other advanced practices.

Having in mind the transition period, data transparency and the poor national investment in research, we can conclude that the national research develops better than expected, but still a lot of efforts should be put forth to keep pace with the international scientific community.

\section{REFERENCES}

[1] W. R. Sutton, J. P. Srivastava, J. E. Neumann, K. B. Strzepek, Kenneth, B. B. Boehlert, Reducing the vulnerability of the Former Yugoslav Republic of Macedonia's agricultural systems to climate change: impact assessment and adaptation options, Agricultural Systems to Climate Change: Impact Assessment and Adaptation Options. World Bank Study, World Bank, Washington, DC, 2013.

[2] S. E. Mustonen, J. L. McGuinness, Lysimeter and watershed evapotranspiration, Water Resour. Res. 3, 4 (1967) pp. 989-996.

[3] G. H. Hargreave, Estimation of potential and crop evapotranspiration. Trans ASAE (Am Soc Agric Eng), 17, 4 (1974), pp. 701-704.

[4] W. O. Pruitt, F. J. Lourence, Experiences in lysimetry for ET and surface drag measurements. Advances in Evapotranspiration (1985), pp. 51-69.

[5] T. A. Howell, A. D. Schneider, M. E. Jensen, History of lysimeter design and use for evapotranspi- 
ration measurements. ASCE International Symposium on Lysimetry, Lysimeters for Evapotranspiration and Environmental Measurements, Honolulu, Hawaii, 1991, Proceedings, pp. 1-9.

[6] C. Liu, X. Zhang, Y. Zhang, Determination of daily evaporation and evapotranspiration of winter wheat and maize by large-scale weighing lysimeter and micro-lysimeter, Agric. For. Meteorol. 111, 2 (2002) pp. 109-120.

[7] R. López-Urrea, F. M. de Santa Olalla, C. Fabeiro, A. Moratalla, Testing evapotranspiration equations using lysimeter observations in a semiarid climate, Agric. Water Manage., 85, 1 (2006), pp 15-26.

[8] F. J. Toyin, R. J. Miguel, O. P. Gbenro, A. A. Ebenezer, Greenhouse evapotranspiration and crop factor of Amaranthus cruentus grown in weighing lysimeters. Afr. J. Agric. Res., 10, 34 (2015), pp 3453-3461.

[9] W. A. Dugas, L. J. Fritschen, L. W. Gay, A. A. Held, A. D. Matthias, D. C. Reicosky, P. Steduto, J. L. Steiner, Bowen ratio, eddy correlation, and portable chamber measurements of sensible and latent heat flux over irrigated spring wheat, Agric. For. Meteorol., 56, 2 (1991), pp. 1-20.

[10] A. G. Barr, K. M. King, T. J. Gillespie, G. Den Hartog, H. H. Neumann, A comparison of Bowen ratio and eddy correlation sensible and latent heat flux measurements above deciduous forest. Bound.-Layer Meteor., 71, 1-2 (1994), pp. 21-41.

[11] A. Wolf, N. Saliendra, K. Akshalov, D. A. Johnson, E. Laca, Effects of different eddy covariance correction schemes on energy balance closure and comparisons with the modified Bowen ratio system, Agric. For. Meteorol., 148, 6 (2008), pp. 942-952.

[12] S. Gebler, H. J. Hendricks Franssen, T. Pütz, H. Post, M. Schmidt, H. Vereecken, Actual evapotranspiration and precipitation measured by lysimeters: a comparison with eddy covariance and tipping bucket, Hydrol. Earth Syst. Sci., 19, 5(2015), pp. 2145-61.

[13] R. J. Reginato, R. D. Jackson, P. J. Pinter, Evapotranspiration calculated from remote multispectral and ground station meteorological data, Remote Sens. Environ., 18, 1 (1985), pp. 75-89.

[14] J. L. Chávez, C. M. Neale, J. H. Prueger, W. P. Kustas, Daily evapotranspiration estimates from extrapolating instantaneous airborne remote sensing ET values, Irrigation sci., 27, 1, (2008), pp. 67-81.

[15] M. Cruz-Blanco, I. J. Lorite, C. Santos, An innovative remote sensing based reference evapotranspiration method to support irrigation water management under semi-arid conditions, Agric. Water Manage., 131, (2014) pp. 135-45.

[16] W. Abtew, J. Obeysekera, Lysimeter study of evapotranspiration of cattails and comparison of three estimation methods, Trans ASAE (Am Soc Agric Eng), 38, 1 (1995), pp. 121-129.
[17] P. S. Kashyap, R. K. Panda, Evaluation of evapotranspiration estimation methods and development of crop-coefficients for potato crop in a sub-humid region, Agric. Water Manage., 50, 1 (2001), pp. 9-25.

[18] J. Marsal, J. Girona, J. Casadesus, G. Lopez, C. O. Stöckle. Crop coefficient $(\mathrm{Kc})$ for apple: comparison between measurements by a weighing lysimeter and prediction by CropSyst. Irrigation Sci., 31, 3 (2013), pp. 455-463

[19] K. C. Reddy, Development of crop coefficient models of castor and maize crops, Eur. J. Agron., 69 (2015), pp. 59-62.

[20] C. W. Thornthwaite, An approach toward a rational classification of climate. Geogr. Rev., 38, 1(1948), pp. 55-94.

[21] H. L. Penman, Natural evaporation from open water, bare soil and grass, P. Roy. Soc. Lond. A Mat., 193, 1032 (1948), pp. 120-145.

[22] H. F. Blaney, K. V. Morin, W. D. Criddle, Consumptive water use and requirements-the Pecos River joint investigation reports of the participating agencies, Natural Resource Planning Board, US Government Printing Office, Washington, DC, 1942 , pp. 170-230.

[23] H. F. Blaney, W. D. Criddle, Determining water requirements in irrigated areas from climatological and irrigation data, Soil conservation service technical paper 96, Soil conservation service, US. Department of Agriculture, Washington, 1950.

[24] G. E. Harbeck, A practical field technique for measuring reservoir evaporation utilizing masstransfer theory, US Government Printing Office, Washington, DC, 1962.

[25] C. H. Priestley, R. J. Taylor, On the assessment of surface heat flux and evaporation using large-scale parameters, Mon. Weather Rev, 100, 2 (1972), pp. 81-92.

[26] G. H. Hargreaves, Moisture availability and crop production, Trans ASAE (Am Soc Agric Eng), 18, 5 (1975), pp. 980-984.

[27] G. H. Hargreaves, Z. A. Samani, Reference crop evapotranspiration from temperature. Appl Eng Agric, 1, 2 (1985), pp. 96-9.

[28] M. E. Jensen, H. R. Haise, Estimating evapotranspiration from solar radiation, Proceedings of the American Society of Civil Engineers, J. Irrig. Drain. Eng, 89 (1963) pp. 15-41.

[29] J. L. Monteith, Evaporation and environment, Symp. Soc. Exp.Biol., 19, 4 (1965), pp. 205-223.

[30] J. Doorenbos, W. O. Pruitt, Crop water requirements, FAO irrigation and drainage paper 24. Land and Water Development Division, FAO, Rome, 1977.

[31] R. G. Allen, L. S. Pereira, D. Raes, M. Smith, Crop evapotranspiration - Guidelines for computing crop water requirements, FAO Irrigation and drainage paper 56, FAO, Rome, 1998. 
[32] I. A. Walter, R. G. Allen, R. Elliott, M. E. Jensen, D. Itenfisu, B. Mecham, T. A. Howell, R. Snyder, P. Brown, S. Echings, T. Spofford, ASCE's standardized reference evapotranspiration equation, $\mathrm{Wa}$ tershed Management 2000 Conference, Fort Collins, Colorado, USA, 2000, Proceedings, pp.1-11.

[33] D. Itenfisu, R. L. Elliott, R. G. Allen, I. A. Walter, Comparison of reference evapotranspiration calculations as part of the ASCE standardization effort, Journal of Irrigation and Drainage Engineering, 129, 6 (2003), pp. 440-448.

[34] R. G. Allen, M. Smith, L. S. Pereira, W. O. Pruitt, Proposed revision to the FAO procedure for estimating crop water requirements, Acta Hort., 449 (1996), pp. 17-34

[35] P. Yang, H. Hu, F. Tian, Z. Zhang, C. Dai, Crop coefficient for cotton under plastic mulch and drip irrigation based on eddy covariance observation in an arid area of northwestern China, Agric. Water Manage., 171 (2016), pp. 21-30.

[36] F. Tian, P. Yang, H. Hu, C. Dai, Partitioning of cotton field evapotranspiration under mulched drip irrigation based on a dual crop coefficient model, Water, 8, 3 (2016) p.72.

[37] T. S. Aamlid, J. W. Knox, H. Riley, A. Kvalbein, T. Pettersen, Crop Coefficients, Growth Rates and Quality of Cool-Season Turfgrasses, J Agron Crop Sci, 202, 1 (2016), pp. 69-80.

[38] J. M. Muniandy, Z. Yusop, M. Askari, Evaluation of reference evapotranspiration models and determination of crop coefficient for Momordica charantia and Capsicum annuum, Agric. Water Manage., 169 (2016), pp. 77-89.

[39] I. Campos, C. Balbontín, J. González-Piqueras, M. P. González-Dugo, C. M. Neale, A. Calera, Combining a water balance model with evapotranspiration measurements to estimate total available soil water in irrigated and rainfed vineyards, Agric. Water Manage., 165 (2016), pp. 141-152.

[40] S. Paparrizos, F. Maris, A. Matzarakis, Sensitivity analysis and comparison of various potential evapotranspiration formulae for selected Greek areas with different climate conditions, Theor. Appl. Climatol., January (2016), pp. 1-5.

[41] Б. Косевски, Потребне количине воде за кукуруз на подручју Скопског Поља и Полога, Годишен зборник на Земјоделско-иумарскиой факулиеей, Скопје, XVIII (1965) стр.113-174.

[42] Иљовски И., Влијание на залевањеиео йри различи

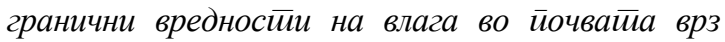

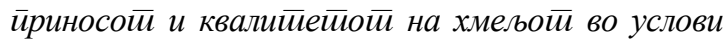
на Пелагонија, Докторска дисертација, Земјоделски факултет - Скопје, 1983.

[43] И. Иљовски, В. Гагачев, А. Демировски, Влијание на вештачкиот дожд врз приносот, квалитетот и некои елементи од биологијата на хмељот, Соц. земј. 1-12 (1986) стр. 1-12.
[44] И. Иљовски, О. Чукалиев, Влијанието на режимот на заливање врз приносот на сончогледот одгледуван како втора култура за зрно, Годимен зборник на Земјоделскиой факулиеей во Скопје, XXXVI, (1991).

[45] О. Чукалиев. И. Иљовски, Уйииај режима заливања на йринос кукуруза гајеног као йосйрна кулйура за зрно, Коришћење $и$ одржавање мелиорачионих сисиеема, посебна публикација, Југословенско друштво за проучавање земљишта, Београд, 1993, стр. 177-182.

[46] И. Иљовски, О. Чукалиев, Д .Мукаетов, Наводнувањето - основен услов за одгледување на шеќерната репа како втора култура, Коришћење и одржавање мелиорационих сисиемма, посебна публикација, Југословенско Друштво за проучавање земљишта, Београд, 1993, стр. 183-188.

[47] O. Chukaliev, I. Iljovski, Micro Sprinkler Irrigation and its Effects on Sugar Beet Yield and Sugar Content, International Symposium Integrated Resource Management \& Landscape Modification for Environmental Protection, Chicago, 1993, Proceedings, pp. 248-253.

[48] И. Иљовски, О. Чукалиев, Влијание на пулсативното заливање врз микроклимата и прино-

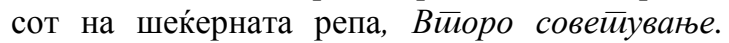

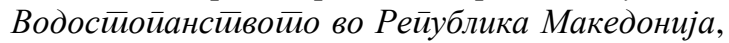
Охрид, Македонија, 1995, стр. 137-141.

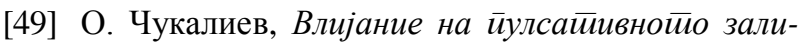

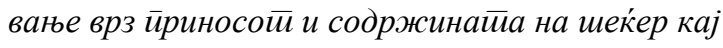
шеќернайа рейа во Скойско, докторска дисертација, Универзитет Св. Кирил и Методиј, Земјоделски факулктет - Скопје, 1996.

[50] И. Иљовски, О. Чукалиев, Микронаводнувањето и неговото влијание врз потрошувачката на вода и вегетативниот прираст кај млад

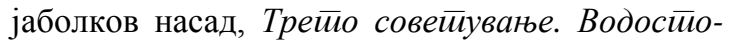

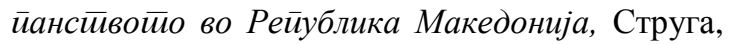
Македонија, 1996, Зборник на трудови, стр. 377-383.

[51] И. Иљовски, О. Чукалиев, Б. Стојанов, Д. Мукаетов, Споредбени резултати од капково и гравитационо наводнување на домати во оранжерија, Јубилеен годимен зборник на Земјоделскиой факулйей, 42, (1997) стр. 8387.

[52] И. Иљовски, Б. Стојанов, О. Чукалиев, Ефекти од наводнувањето капка по капка кај некои сорти и хибриди индустриски домат, Јубилеен

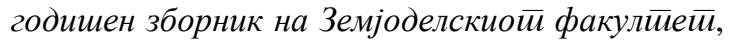
42, (1997) стр. 89-93.

[53] И. Иљовски, О. Чукалиев, Резултатите од примената на пулсативното наводнување кај

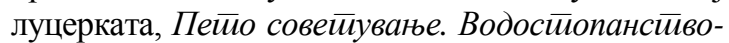
йо во Рейублика Македонија, Струга, Македонија, 1998, Зборник на трудови, стр. 93-98. 
[54] I. Iljovski, O. Chukaliev, B. Ristevski, Water conservation as important method in fight against drought, International Symposium "Drought and Plant Production", Lepenski Vir, Yugoslavia, 1997, Proceedings, pp. 159-164.

[55] O. Chukaliev, I. Iljovski, The results of comparative research of tomato irrigated with drip and furrow irrigation, International Eco-Conference 2000, Novi Sad, Yugoslavia, 2000, Proceedings, pp. 179-183.

[56] Ж. Јанкуловски, И. Иљовски, О. Чукалиев, Режим на залевање кај шеќерната репка и специфичната потрошувачка на вода во

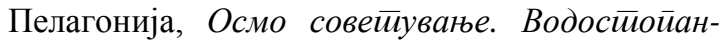

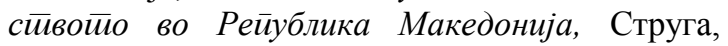
Македонија, 2001, Зборник на трудови, стр. 149-154.

[57] И. Иљовски, Хидро-фитотермичкиот коефициент како основа за определување на нормата и времето на залевање кај хмељот, Јубилеен

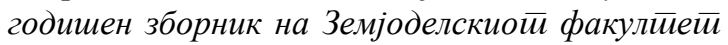
- Cкопје XXXIV (1988), стр.63-72.

[58] О. Чукалиев, Основнийе хидройедолошки свој-

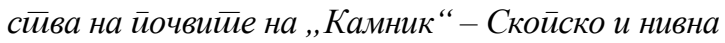

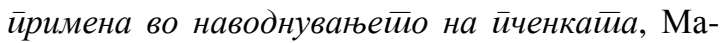
гистерска работа, Скопје, 1991.

[59] О. Чукалиев, И. Иљовски, Модул на наводнување на кајсијата во ХС “Лисиче”, Факулиеиеи-

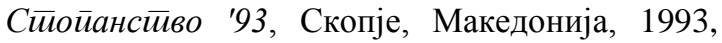
Зборник на трудови, стр.163-168.

[60] О. Чукалиев, И. Иљовски, Математички модел на потрошувачката на вода за домати одгледувани во ХС “Лисиче”, “Нови йехнологии во

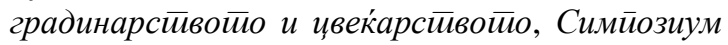
со меѓународно учесӣво, Охрид, Македонија, 1994, Зборник на трудови, стр. 291-298.

[61] Ж. Јанкулоски, О. Чукалиев, Д. Китановски, В. Танасковиќ, Ефекти на наводнувањето и ѓубрењето врз приносот на шеќерната репа,

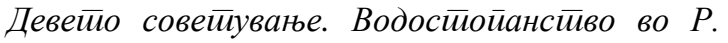
Македонија, Охрид, Македонија, 2003, Зборник на трудови, стр. 243-249.

[62] В. Танасковиќ, Влијание на ферӣиригаџијайа

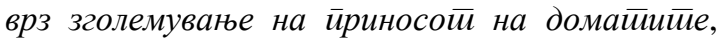
Магистерски труд, Факултет за земјоделски науки и храна, Универзитет Св. Кирил и Методиј, Скопје, 2005.

[63] В. Танасковиќ, О. Чукалиев, И. Иљовски, Примена на методата на воден биланс за определување на потрошувачката на вода (ET)

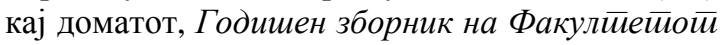
за земјоделски науки и храна - Скопје, 51, (2006), стр. 65-74.

[64] В. Танасковиќ, О. Чукалиев, И. Иљовски, Влијание на начинот и режимот на наводнување и прихрана врз приносот на доматот, Јубилеен годишен зборник “60 години Факул- $\bar{u} е \bar{u}$ за земјоделски науки и храна-Скойје”, 53, (2007), стр. 137-149.

[65] O. Chukaliev, I. Iljovski, V. Tanasković, "Nitrogen use efficiency in irrigated tomato crop", International Conference on Soil Fertility and Diversity in Mediterranean Agriecosystems \& Organic World Conference \& 4th General Assembly of IFOAM Agribiomediterraneo", Ohrid, 2005.

[66] В. Танасковиќ, Режим на наводнување на йииеркайа со микро-наводнување и негово влија-

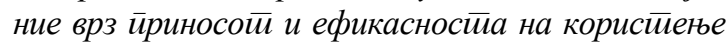
на водайа во Скойско, Докторска дисертација, Факултет за земјоделски науки и храна, Универзитет Св. Кирил и Методиј, Скопје, 2009.

[67] V. Tanasković, O. Cukaliev, D. Romić, G. Ondrašek, The influence of drip fertigation on water use efficiency in tomato crop production, Agric. Conspec. Sci. (ACS), 76, 1 (2011), 57-63.

[68] V. Tanasković, O. Chukaliev, Z. Jankuloski, M. Markoski, I. Iljovski, S. Nechkovski, Determination of evapotranspiration under different irrigation and fertilization techniques in green pepper crop production, International Symposium for Agriculture and Food, Skopje, Macedonia, 2012, pp.

[69] V. Tanasković, O. Chukaliev, M. Markoski, B. Srdjevic, V. Spalevic, I. Simunic, M. Moteva, N. Djurovic, The influence of irrigation and drip fertigation regime on specific water consumption and evapotranspiration coefficient in tomato crop production. AgricultForest, 60, 4 (2014), pp. 243-254.

[70] V. Tanasković, O. Chukaliev, M. Moteva, M. Jankulovska, M. Markoski, V. Spalevic, R. Rusevski, Z. Bogevska, M. Davitkovska, The influence of irrigation and fertilization regime on some phenological stages and earliness of pruned pepper. Agricult Forest, 61, 2 (2015) pp. 7-17.

[71] O. Chukaliev, V. Tanasković, R. S. Kanwar, L. Heng Kheng, D. Mukaetov, Irrigation and fertigation effects on nitrogen use efficiency \& tomato yield. International Agricultural Engineering Journal, 17 (1-4): (2008), pp. 19-26.

[72] Б. Петровски, Воден режим во мелиоративното подрачје на Скопско Поле, Годишен зборник на

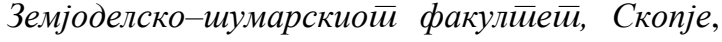
XVII (1964), стр. 176-204.

[73] B. Ćosevski, S. Popov, Consumptive use of water and optimal dampnes of a soil layer for peper grown in Ovče Pole, XIX congress on Horticulture, Warsaw, Poland, 1975.

[74] I. Iljovski, K. Vasilkovski, A. Demirovski, Potrebne količine vode za navodnjavanje Opitnog Polja Poljoprivrednog instituta iz Skoplja, Vodoprivreda, 42, (1976).

[75] И. Иљовски, Потреба од изработка на Земјоделски основи за димензионирање на акумулациите со поголем капацитет, Билиеен на 


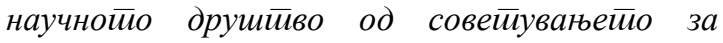
микроакумулации, Прилеп, Македонија, 1990.

[76] О. Чукалиев, И. Иљовски, Математички модел на потрошувачката на вода за домати одгледувани во ХС “Лисиче", "Нови йехнологии во

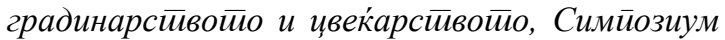
со меѓународно учесӣво, Охрид, Македонија, 1994, Зборник на трудови, стр. 291-298.

[77] И. Иљовски, О. Чукалиев, ЕТР и дефицит на вода за застапената структура на култури во Република Македонија, Совейување "Водо-

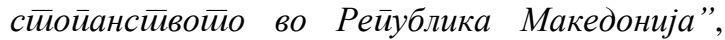
Струга, Македонија, 1994, стр. 111-114

[78] Ѓ. Филиповски, Р. Ризовски, П. Ристевски,

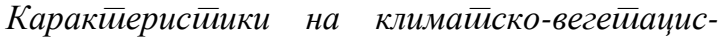
кийе йочвени зони (региони) во Р. Македонија, МАНУ, Скопје, 1996, стр. 177.

[79] И. Иљовски, О. Чукалиев, Почвено-климатски услови и ЕТР на подрачјето на ХС “Лисиче" за

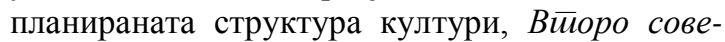

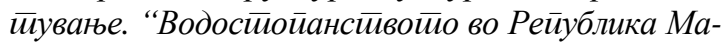
кедонија”, Охрид, Македонија, 1995, Зборник на трудови, стр. 127-136.

[80] И. Иљовски, О. Чукалиев, Водни ресурси и современи методи за определување на ЕTР за планираната структура на култури во Репу-

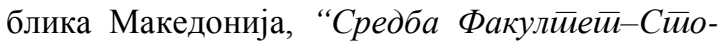
йансииво”' '96, Скопје, Македонија, 1996, Зборник на трудови, стр. 69-77.

[81] O. Chukaliev, I. Iljovski, Z. Jankulovski, D. Mukaetov, P. Ristevski, Evapotranspiration and water deficiency in Bitola area of Pelagonia and their effect on wheat yield, 2nd Balkan Symposium on Field Crops, Novi Sad, Yugoslavia, 1998, Proceedings, pp. 513-517.

[82] J. Doorenbos, A. H. Kassam, Yield response to water. Irrigation and drainage paper No. 33, FAO, Rome, 1979, pp. 257.

[83] P. Steduto, T. C. Hsiao, E. Fereres, D. Raes, Crop yield response to water. Food and Agriculture Organization of the United Nations; Rome, 2012.

[84] E. Ančev, I. Iljovski, D. Jankulovski, O. Chukaliev, Drought incidence and influence on crop production and environment in the Republic of Macedonia, Balkan Drought Workshop, Zajecar, Yugoslavia, 1998, Proceedings, pp.135-145.

[85] E. Ančev, I. Iljovski, D. Jankulovski, O. Cukaliev, Drought influence on crop production in major agricultural areas in the Republic of Macedonia, Central and Eastern European Workshop on Drought Mitigation, Balkan Drought Workshop, Budapest, Hungary, 2000, Proceedings, pp.121-128.

[86] И. Иљовски, О. Чукалиев, Ж. Јанкуловски, Определување на потребите од вода за наводнување на планираната структура на култури значаен услов за водостопанската основа,

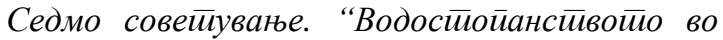

Реӣублика Македонија”, Струга, Македонија, 2000, Зборник на трудови, стр. 327-330.

[87] Group of authors, Second National Communication on Climate Change, Ministry for environment and physical planning, UNDP - Skopje, 2008, pp 128.

[88] V. Tanasković, O. Chukaliev, Z. Jankuloski, M. Markoski, I. Iljovski, S. Nechkovski, (2013). Determination of evapotranspiration under different irrigation and fertilization techniques in green pepper crop production. International Symposium for Agriculture and Food, Skopje, Macedonia, 2013, Proceedings, pp. 755-768.

[89] V. Tanasković, O. Cukaliev, V. Spalevic, M. Markoski, S. Nechkovski, The effect of irrigation and fertilization techniques on specific water consumption of green pepper. The 1st International Congress on Soil Science, XIII National Congres in Soil Science, Soil-Water-Plant, Belgrade, Serbia, 2013, pp. 409-423.

[90] О. Чукалиев, И. Иљовски, Н. Алексовска, Л. Трајановска, Ж. Јанкуловски, Влијанието на климатските промени и методата за определување на ефикасните врнежи врз пресметките на потребите од вода за наводнување,

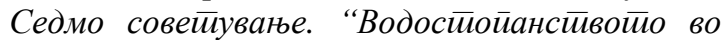
Рейублика Македонија”, Струга, Македонија, 2000, Зборник на трудови, стр. 331-338.

[91] N. G. Dastane, Effective rainfal in Irrigated Agriculture, FAO Irrigation and drainage paper 25, FAO, Rome, 1978.

[92] Group of authors, First National Communication of Republic of Macedonia to UNFCCC, Ministry for Environment and Physical Planning, UNDP, Skopje, 2003, pp. 144.

[93] C. V. Diepen, J. Wolf, H. V. Keulen, C. Rappoldt, WOFOST: A simulation model of crop production. Soil Use and Management, 5, 1 (1989) pp.16-24.

[94] C. O. Stöckle, M. Donatelli, R. Nelson, CropSyst, a cropping systems simulation model. Eur. J. Agron., 18, 3 (2003), pp. 289-307.

[95] J. W. Jones, G. Hoogenboom, C. H. Porter, K. J. Boote, W. D. Batchelor, L. A. Hunt, P. W. Wilkens, U. Singh, A. J. Gijsman, J. T. Ritchie, The DSSAT cropping system model. Eur. J. Agron., 18, 3 (2003), pp. 235-65.

[96] N. Brisson, C. Gary, E. Justes, R. Roche, B. Mary, D. Ripoche, D. Zimmer, J. Sierra, P. Bertuzzi, P. Burger, F..Bussiere, An overview of the crop model STICS. Eur. J. Agron., 18, 3 (2003), pp. 309-32.

[97] Group of authors, Third National Communication on Climate Change, Ministry for Environment and Physical Planning, UNDP, Skopje, 2014, pp 231.

[98] BioMA - Biophysical Models Applications, http://bioma.jrc.ec.europa.eu/index.htm / 
[99] D. Mukaetov, Z. Dimov, K. Boskov, O. Cukaliev, E. Poposka, Climate change impact on viticulture in Povardarie region of Macedonia-assesment and adaptation, AgricultForest 60, 4 (2014), pp. 87-93.

[100] J. M. Callaway, N. Markovska, O. Chukaliev, A. Causevski, D. Gjoshevski, V. Taseska, S. Nikolova, Assessing the Economic Impact of Climate Change: National Case studies. UNDP - Skopje, 2011.

[101] K. Bergant. Climate Change Scenarios for Macedonia: Review of Methodology and Results. University of Nova Gorica, Centre for Atmospheric Research, Nova Gorica, 2006.

[102] D. Buzarovska, Optimization of agricultural production under climate change up to 2050 in Pelagonia region, Master thesis, SLU Upsala, Sweden, 2012.

[103] G. Duvellier, A. Ceglar, O. Chukaliev, S. Niemeyer, Evaluating the capacity to grasp extreme values of agro-climatic indices under changing climate conditions over Europe, International Conference on Climate Change Effects Impacts World 2013, Potsdam, Germany, 2013, Proceedings 246-253.

[104] A. Ceglar, O. Chukaliev, G. Duvellier, S. Niemeyer, Water requirements for maize production in Europe under changing climate conditions, Proceedings of International Conference on Climate Change Effects Impacts World 2013, Potsdam, Germany, 2013, Proceedings, pp. 78-86.

[105] A. Ceglar, O. Chukaliev, R. Lecerf, S. Niemeyer, Comparing the performance of different irrigation strategies for producing grain maize in Europe, MACSUR Conference Modelling Climate Change Impacts on Crop Production for Food Security, Oslo, Norway, 2014, Abstracts Book, p. 66.

[106] Z. Dimov, D. Mukaetov, O. Chukaliev, L. Dimitrov, V. Tanaskovik, I. Iljovski, Design of agronomical measures for winter wheat and sunflower productivity to mitigate climate changes in southeastern Macedonia, $5^{\text {th }}$ Croatian and $11^{\text {th }}$ International Symposium on Agriculture, Opatija, Croatia, 2016, Proceedings, pp. 218-222.

\title{
ПРЕГЛЕД НА ИСТРАЖУВАҢАТА НА ПОТРЕБАТА ОД ВОДА ЗА ЗЕМЈОДЕЛСКИТЕ КУЛТУРИ И НИВНА ПРИМЕНА ВО РЕПУБЛИКА МАКЕДОНИЈА
}

\author{
Ордан Чукалиев
}

\author{
Факултет за земјоделски науки и храна, Универзитет „Св. Кирил и Методиј”, \\ Скопје, Република Македонија
}

\begin{abstract}
Трудот дава преглед на истражувачките активности врз евапотранспирацијата (ЕT), потребата од вода за земјоделските култури (ПВЗК) и употребата на овие параметри во други истражувања, пред се истра/увањата на климатските промени. Во првиот дел на трудот се разгледуваат за достигнувањата во овие истражувања на светското ниво. Потоа се дискутира за постигнувањата на домашните научноистражувачки активности. Македонија нема развиено капацитети за мерење на ЕТ и ПВЗК. Се применува само една практика - полски опити за определување на водниот биланс под претпоставка дека нема движење на вода во зоната на ризосферата. Определувањето на ЕТ пред сѐ е базирано на примена на процедурата ФАО 56 (Пенман-Монтеит процедура). Поради недостиг на податоци потребни за помасовна примена на оваа методологија се применува методологијата на Торнтвајт, која има помалку интензивни барања за влезни податоци. ЕТ и ПВЗК во земјата се користат при изработка на проекти за наводнување , во научноистражувачките активности и при определување на ефект од недостигот на вода врз приносите на земјоделските култури, пред сѐ во услови на климатски промени. Во последно време се изведени активности за примена на некои биофизички модели како што ce WOFOST и CropSyst.
\end{abstract}

Клучни зборови: евапотранспирација; потреба за вода на земјоделките култури; климатски промени; научни истражувања; Република Македонија 